Article

\title{
Incorporating Rainfall-Runoff Events into Nitrate-Nitrogen and Phosphorus Load Assessments for Small Tile-Drained Catchments
}

\author{
Petr Fučík ${ }^{1, *}$ (1) , Antonín Zajíček ${ }^{1}$, Markéta Kaplická ${ }^{1}$, Renata Duffková ${ }^{1}$, Jana Peterková ${ }^{1}$, \\ Jana Maxová ${ }^{1}$ and Šárka Takáčová ${ }^{2}$ \\ 1 Research Institute for Soil and Water Conservation, Prague; Zabovreska 250, 15627 Praha-Zbraslav, \\ Czech Republic; zajicek.antonin@vumop.cz (A.Z.); kaplicka.marketa@vumop.cz (M.K.); \\ duffkova.renata@vumop.cz (R.D.); peterkova.jana@vumop.cz (J.P.); maxova.jana@vumop.cz (J.M.) \\ 2 Prague, Č́lova 277/13, 16200 Praha 6-Veleslavín, Czech Republic; sarka.takacova@img.cas.cz \\ * Correspondence: fucik.petr@vumop.cz; Tel.: +42-(0)2-5702-7208
}

Received: 2 June 2017; Accepted: 13 September 2017; Published: 16 September 2017

\begin{abstract}
Rainfall-runoff events significantly influence water runoff and the loss of pollutants from tile-drained agricultural land. We monitored ten small (4 to 38 ha) tile-drained catchments in Czechia for three to five years (2012 to 2016). The discharge was measured continuously; a regular 14-day scheme of water quality monitoring was accompanied with event sampling provided by automatic samplers in 20 to $120 \mathrm{~min}$ intervals. A new semi-automated algorithm was developed for the identification of runoff events (RE) based on discharge and water temperature changes. We then quantified the share of RE on the total runoff and the $\mathrm{N}$ and P losses, and we compared six methods for nutrient load estimation on an annual and monthly basis. The results showed considerable differences among the monitored sites, seasons, and applied methods. The share of RE on N loads was on average $5 \%$ to $30 \%$ of the total annual load, whereas for P (dissolved and total), the share of RE was on average $10 \%$ to $80 \%$ on the total annual load. The most precise method for nutrient load estimation included the RE. The methods based on point monitoring of the discharge and water quality underestimated the loads of $\mathrm{N}$ by $10 \%$ to $20 \%$ and of $\mathrm{P}$ by $30 \%$ to $80 \%$. The acquired findings are crucial for the improvement of nutrient load assessment in tile-drained catchments, as well as for the design of various mitigation measures on tile-drained agricultural land.
\end{abstract}

Keywords: runoff events; tile drainage; load assessment methods; nitrate; phosphorus

\section{Introduction}

There is great concern among hydrologists, watershed managers, and as policy makers about how different rainfall-runoff events influence hydrology as well as the loss of pollutants from tile-drained agricultural land [1,2]. Intensively managed tile-drained landscapes have been found to have a considerable potential for $\mathrm{N}$ and $\mathrm{P}$ losses, with regard to different soil conditions and cropping systems, especially during periods with elevated flows [3-9]. Nutrient concentrations in drainage waters may change rapidly within a rainfall-runoff event due to variable pre-event and event soil/catchment moisture conditions, related soil biogeochemical processes [10-13], precipitation characteristics, and water flow paths into drainage and with different origin and residence times [14-17].

Tile-drained fields and catchments of various scales have been subject to many studies trying to quantify how different sampling strategies, monitoring schemes, and load calculation methods influence the assessment of runoff and nutrient fluxes from tile drains, from one season to longer periods. While there is in-depth research for individual fields or paired catchments $[8,14,18-21]$, not many mid-term studies have been conducted to compare nutrient losses and load assessment 
methods for tile-drained fields or small catchments with different agricultural management and runoff characteristics, especially in central European conditions. In the Czech Republic, around $30 \%$ of the agricultural land is tile-drained, and in some regions land drainage exists on every field [22,23].

The basic classification of load estimation methods is usually in four categories: averaging methods, ratio estimators, period-weighted, and regression methods. For nitrate-N load estimation, two methods have been recommended by numerous authors: (1) linear interpolation, a period weighted method, and (2) flow-weighted mean concentration, an averaging method [18,24,25]. Previous research has shown that the uncertainty due to infrequent sampling and nutrient load estimation approaches for drainage systems or small streams is often much greater than the uncertainty brought about by other steps in the sample collection process [25-27]. In general, the uncertainties in annual or monthly nutrient load estimates are reported to be influenced both by the sampling interval and the load assessment methods and tend to increase with an increasing sampling interval for the majority of load estimation algorithms $[24,25,28]$. Ratio methods are often reported as bei ng unsatisfactory compared with the two aforementioned simple methods. Regression based algorithms are also found to poorly characterize load variation (especially for nitrates) in drainage or small watercourses $[27,29]$ despite the implementation of error correction techniques $[20,30]$.

To our knowledge, only a few studies have been published to compare monitoring approaches and nutrient load assessment methods for tile-drained fields or small catchments $[6,25,27,31]$. These studies often conclude that the most dominant factors influencing nutrient fluxes are precipitation characteristics and catchment hydrological connectivity. This pertains, compared to nitrogen, to a greater extent to phosphorus, as high $\mathrm{P}$ concentrations in water from land drainage are associated predominantly with elevated flows, both from ploughland and grassland [4,5,32-34]. Load assessment approaches without continuous discharge measurements and event sampling tend to underestimate $P$ loads especially [33,35]. However, little is still known about how and to what extent various nutrient load assessment approaches, including those used in operational activities (e.g., of River Basin Authorities) may differ for small, tile-drained catchments, situated in sloping conditions. Further, there is an obvious research gap in the knowledge of the hydrological behaviour of small, tile-drained catchments with different soil and land-use characteristics, especially during various rainfall-runoff events captured by different monitoring strategies $[1,36]$.

The necessity of the accurate assessment of nutrient loads from tile-drained fields or small catchments is invoked by watershed management and agricultural policy aims oriented towards diminishing nutrient and pesticides losses from drained land [2,36,37]. Therefore, it is crucial to develop an approach to identify the processes responsible for the input of pollutants from land to water via tile drainage. To reveal the rapid discharge/concentration changes, describe the related processes, and estimate the true pollutant loads, a proper monitoring programme and appropriate methods for the evaluation of matter fluxes are necessary to support $[6,18,38]$ the design of field to catchment scale mitigation measures for tile drainage or on drained land, as well as when estimating their effects $[2,9,22,38-40]$.

The aim of this study was to quantify the proportion of $\mathrm{N}$ and $\mathrm{P}$ losses in drainage waters from runoff events, assess the real $\mathrm{N}$ and $\mathrm{P}$ losses, and to compare six different methods for $\mathrm{N}$ and $\mathrm{P}$ load estimation at ten very small tile-drained catchments with different drainage and agricultural management characteristics in Czechia on a monthly and annual basis in three to five hydrological years between 2012 and 2016 .

\section{Materials and Methods}

\subsection{Experimental Sites}

The research was conducted in the Bohemo-Moravian Highlands, Czech Republic. The catchment areas were 4 to $38 \mathrm{ha}$, and the sites were monitored for three to five hydrological years. These sites represent the prevailing soil types and agricultural management practices across the Czech Highland 
region. At all the sites, tile drainage is located on slopes of $3^{\circ}$ to $6^{\circ}$. The substrate of the sites is crystalline rocks, i.e., various forms of paragneiss, ortogneiss, or granite. Soils at the sites are heterogenous; in discharge areas (mid to low parts of slopes), there are usually stagnic cambisols, haplic stagnosol, haplic gleysols, and sporadically histosols (sandy clay loam/loam) [41]. In the recharge areas (upper slope parts, close to catchment boundaries), there are haplic and shallow haplic cambisols and cambic hyperskeletic leptosol (loamy sand/sandy loam) [41]. Artificial drainage is placed 0.9 to $1.1 \mathrm{~m}$ below the soil surface, drain spacing is between 10 to $18 \mathrm{~m}$, and, since the drainage is built on slopes, the hydrologically contributing area (subcatchment) for a drainage group is far larger than the drained field itself $[15,17,42,43]$. The average annual precipitation at the sites ranged between 550 and $750 \mathrm{~mm}$. On ploughland, cereals, oil seed rape, maize, and, to a lesser extent, potatoes were the typical planted crops. Ploughland catchments were fertilized on average by 120 to $180 \mathrm{~kg} \mathrm{~N} \cdot \mathrm{ha}^{-1} \cdot \mathrm{y}^{-1}$ and by 20 to $30 \mathrm{~kg} \mathrm{P} \cdot \mathrm{ha}^{-1} \cdot \mathrm{y}^{-1}$. The sites PD1 and PD2, where maize was grown, were fertilized by 250 to $300 \mathrm{~kg} \mathrm{~N} \cdot \mathrm{ha}^{-1} \cdot \mathrm{y}^{-1}$. The basic characteristics of the sites are given in Table 1, and the locations of the sites are depicted in Figure 1.

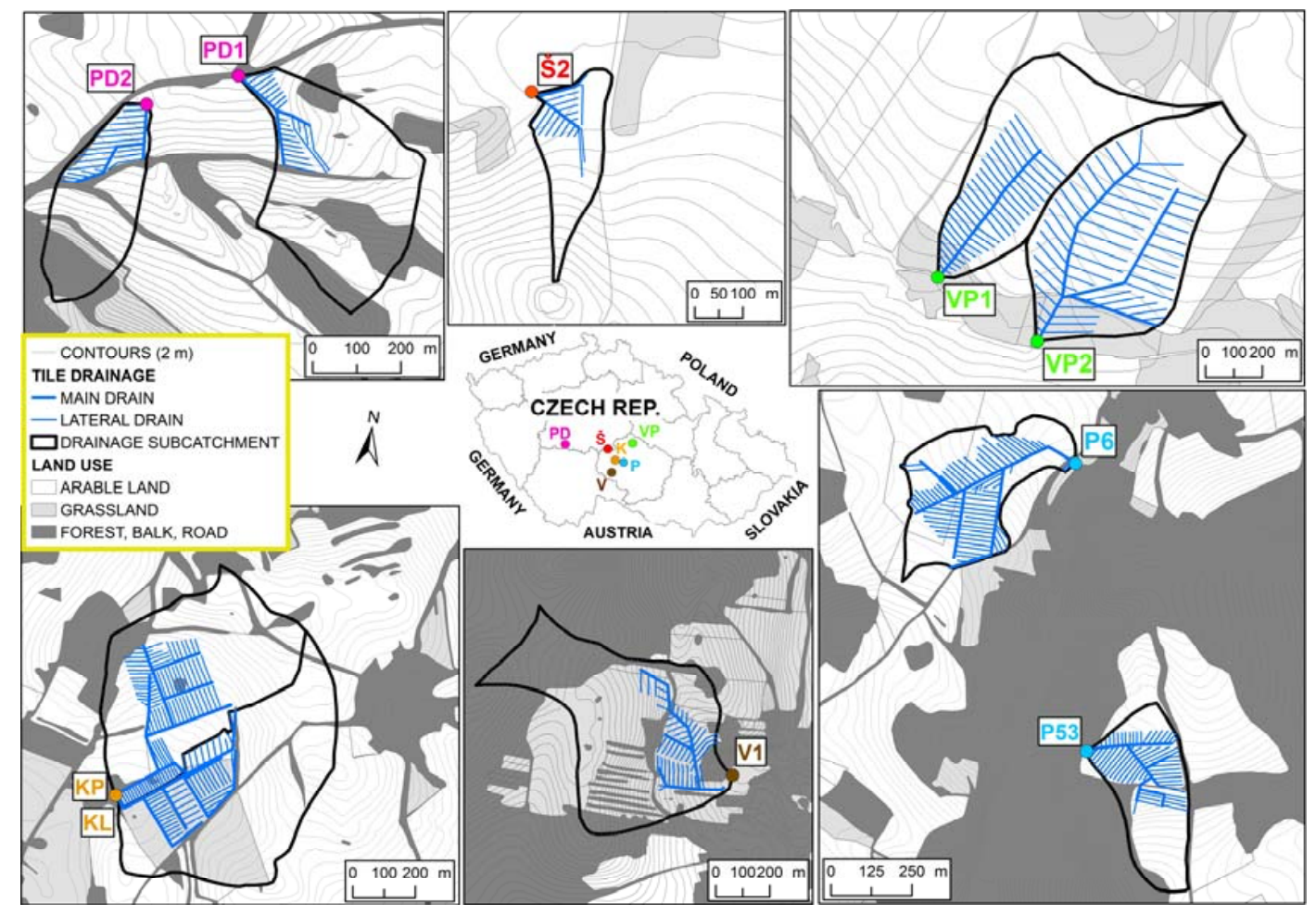

Figure 1. Characteristics and location of the monitored sites in the Czech Republic.

Table 1. Basic characteristics of the monitored sites.

\begin{tabular}{|c|c|c|c|c|c|c|c|c|}
\hline Site & $\begin{array}{l}\text { Mean Catchment } \\
\text { Altitude (m a.s.l.) }\end{array}$ & $\begin{array}{c}\text { Drained } \\
\text { Area } \\
\text { (ha) }\end{array}$ & $\begin{array}{c}\text { Catchment } \\
\text { Area } \\
\text { (ha) }\end{array}$ & $\begin{array}{l}\text { Primary } \\
\text { Land Use }\end{array}$ & $\begin{array}{c}\text { Avg. } \\
\text { Discharge } \\
(1 / s)\end{array}$ & $\begin{array}{c}\text { Specific } \\
\text { Discharge } \\
\text { (1/s/ha) }\end{array}$ & Fertilization/Management & $\begin{array}{c}\text { Evaluated } \\
\text { Period } \\
\text { (HR) }\end{array}$ \\
\hline KL & 550 & 6.51 & 29.6 & grassland & 0.219 & 0.007 & Digestate & $2012-2016$ \\
\hline P53 & 565 & 5.46 & 14.86 & arable land & 0.045 & 0.003 & Mineral & 2012-2016 \\
\hline P6 & 510 & 9.85 & 15.73 & arable land & 0.559 & 0.036 & Mineral & 2012-2016 \\
\hline PD1 & 395 & 1.92 & 13.42 & arable land & 0.307 & 0.023 & Digestate & 2014-2016 \\
\hline V1 & 655 & 5.85 & 37.9 & pasture & 0.993 & 0.026 & Cattle grazing & 2012-2014 \\
\hline VP1 & 495 & 8.68 & 19.95 & arable land & 0.57 & 0.028 & Fugate + mineral & 2014-2016 \\
\hline VP2 & 495 & 21.32 & 28.25 & arable land & 0.705 & 0.025 & Fugate + mineral & 2014-2016 \\
\hline
\end{tabular}




\subsection{Monitoring the Setup and Analyses of Samples}

The drainage discharges were measured continuously at the sites of all drained catchments (manholes or drainage outlets) using ultrasound water level sensors and calibrated weirs (see example in Figure 2). Further, drainage water temperatures were monitored continuously and used as a proxy for the detection and selection of unsampled discharge events; the details are given below. At each site, a weather station measured precipitation and selected meteorological parameters. The withdrawal of water samples differed according to the discharge situation. During periods of prevailing baseflow and slow interflow, the samples were collected manually in a regular two-week step (grab sampling). During runoff events (RE), samples were taken by automatic samplers (ISCO, Morava) in time steps varying from $20 \mathrm{~min}$ (summer events) to $2 \mathrm{~h}$ (winter events). Sampling was activated by an increase of drainage discharge. The particular discharge level that triggered automatic sampling was set according to the precipitation forecast and with regard to previously measured discharges. On average six (4 to 8) samples were taken during a single sampled RE. Immediately after withdrawal, the samples were transported to an accredited laboratory, where they were analyzed for $\mathrm{N}-\mathrm{NO}_{3}, \mathrm{P}-\mathrm{PO}_{4}$, and total phosphorus $\left(\mathrm{P}_{\text {tot }}\right)$ by an automated SKALAR device using Flow Injection and Continuous Flow Analyses (spectrophotometry).

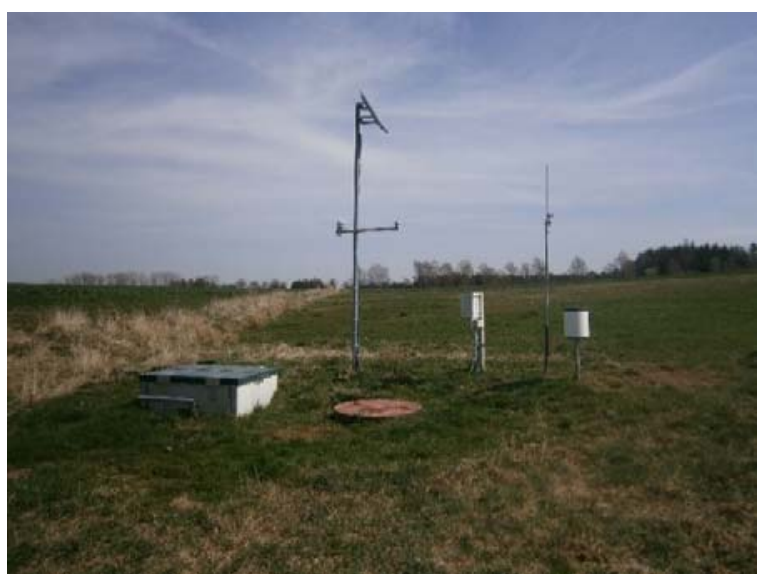

(a)

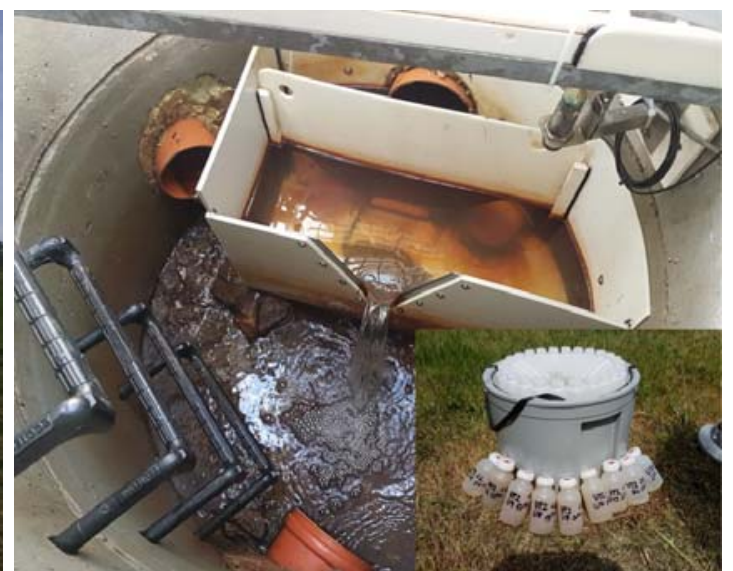

(b)

Figure 2. An example of sampling site equipment. (a): site Š2; (b): site VP2.

For the identification of the REs, a new semi-automated algorithm was developed, taking into account previously published approaches $[29,44]$. A RE was considered as an episodic drainage runoff, elevated by rainfall or snowmelt. The algorithm for the detection of an RE was based on a 10-min discharge and water temperature data record. The algorithm identified a RE, based on the following criteria: drainage discharge for at least $3 \mathrm{~h}$ exceeding 1.5 times the mean daily discharge of the previous day. The beginning of a RE took place when the drainage discharge rose by $10 \%$ or more within $2 \mathrm{~h}$. This eliminated short-term discharge changes during very low flow conditions or due to weir clogs. The end of a RE was set when the drainage water temperature became stable for $>2 \mathrm{~h}$ so no event water appeared in the drainage discharge [17]. Runoff events with several flow peaks were considered as one RE if the time between the consecutive flow peaks was less than $24 \mathrm{~h}$. The procedure for the identification of REs was applied to all REs, no matter whether they were sampled or not. An example of the use of the aforementioned method is shown in Figure 3. 


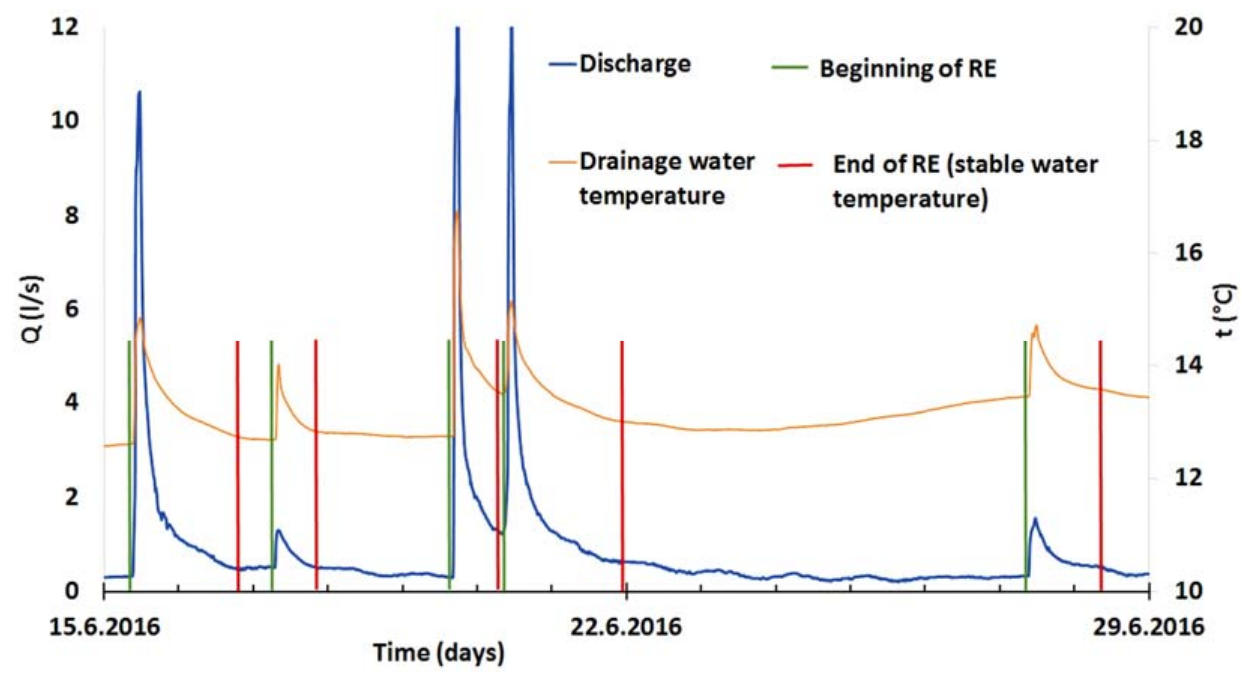

Figure 3. Using the semi-automated algorithm for the identification of REs; an example from the VP2 site.

\subsection{Description of Applied Load Assessment Methods}

For the load assessment of $\mathrm{N}-\mathrm{NO}_{3}, \mathrm{P}_{-} \mathrm{PO}_{4}$, and $\mathrm{P}_{\text {tot }}$, six different methods (M1 to M6) using annual (a) and/or monthly ( $\mathrm{m}$ ) time scales were employed and compared. M1 to M3 are commonly used techniques when 14 to 30 day grab sampling schemes are followed. The descriptions and equations of these methods are given in Table 2. Nutrient loads were further converted to year- and area-specific losses, dividing the load by the drainage subcatchment area. For load assessments in the unsampled RE (M6), flow-weighed concentration values ( $C f w$ ) from a particular season (veg; April to September/non-veg; October to March/snow melt) were used to calculate the loads during these events. The calculation of the Cfw was as follows:

$$
C f w=\frac{\sum(C i \times Q i)}{\sum Q i}
$$

where $C f w$ is the flow-weighted concentration, $C i$ is the concentration value during an $i$ withdrawal, and $Q i$ is the discharge during $i$ withdrawal. $C f w$ was further employed for the basic description of the hydrochemical behaviour of the individually monitored sites (Table 3). The nutrient loads according to $M 6$ were considered the 'true load'.

Table 2. The load assessment methods employed and compared in this study.

\begin{tabular}{lll}
\hline Method & Description & Equation \\
\hline M1 & Load $(a)=$ Mean year discharge $\times$ mean annual concentration (both from 14 day sampling values) & $L=K\left(Q_{a} C_{a}\right)$ \\
\hline M2 & $\begin{array}{l}\text { Load }(a)=\text { Cumulative annual runoff volume (from } 10 \text { min data) } \times \text { flow-weighted concentration (from } \\
\text { 14 day sampling values) }\end{array}$ & $L=K\left(V_{a} C_{f w}\right)$ \\
\hline M3 & $\begin{array}{l}\text { Load }(a, m)=\text { Actual discharge (from sampled days only) } \times \text { concentration (from 14 day sampling } \\
\text { values). For the unsampled days, a load of the previous } / \text { next sampling day is set. }\end{array}$ & $L=K\left(\sum_{i=1}^{n} Q C_{i} C_{i}\right)$ \\
\hline M4 & $\begin{array}{l}\text { Load }(a, m)=\text { Mean daily discharge (from 10 min data in all days) } \times \text { concentration (from 14 day } \\
\text { sampling values). For the unsampled days, a concentration of the previous /next sampling day is set. }\end{array}$ & $L=K\left(\sum_{i=1}^{n} Q d_{i} C_{i}\right)$ \\
\hline M5 & $\begin{array}{l}\text { Load }(a, m)=\text { Mean daily discharge (from 10 min data in all days) } \times \text { concentration (from 14 day } \\
\text { sampling values). For the unsampled days, a linear interpolation of the concentration is used from the } \\
\text { consecutive sampled days }\end{array}$ & $L=K\left(\sum_{j=1}^{n} Q d_{i} C_{j}^{i n t}\right)$ \\
\hline M6 & $\begin{array}{l}\text { Load }(a, m)=\text { M5 + loads during runoff eventsThis method was the only one to include runoff events, } \\
\text { both sampled and unsampled (modelled). }\end{array}$ & $L=K\left(\sum_{j=1}^{n} Q d_{i} C_{j}^{i n t}\right)+K\left(\sum_{e=1}^{n} Q_{e} C_{e}\right)$ \\
\hline
\end{tabular}

$K$ is the units and time conversion constant; $Q a$ is the mean annual discharge; $C a$ is the mean annual concentration; $\mathrm{Va}$ is the cumulative annual runoff volume; $C f w$ is the flow-weighted concentration; $Q i$ is the actual discharge in time of sampling; $\mathrm{C} i$ is the concentration from grab sampling; $Q d$ is the mean daily discharge; $V d$ is the cumulative daily runoff volume (from $10 \mathrm{~min}$ data); Cjint is the linear interpolation of concentration values between the consecutive grab samples; $Q e$ is the actual discharge during an event; $C e$ is the actual concentration during an event, whether measured or modeled; $C f w$ is flow-weighted concentration; and $n$ is the number of days. 
Table 3. The share of runoff events in the total annual drainage runoff and in $\mathrm{N}-\mathrm{NO}_{3}, \mathrm{P}-\mathrm{PO}_{4}$, and $P_{\text {tot }}$ total annual loads and the share of runoff events on average within one HR for the monitored hydrological years at all the sites.

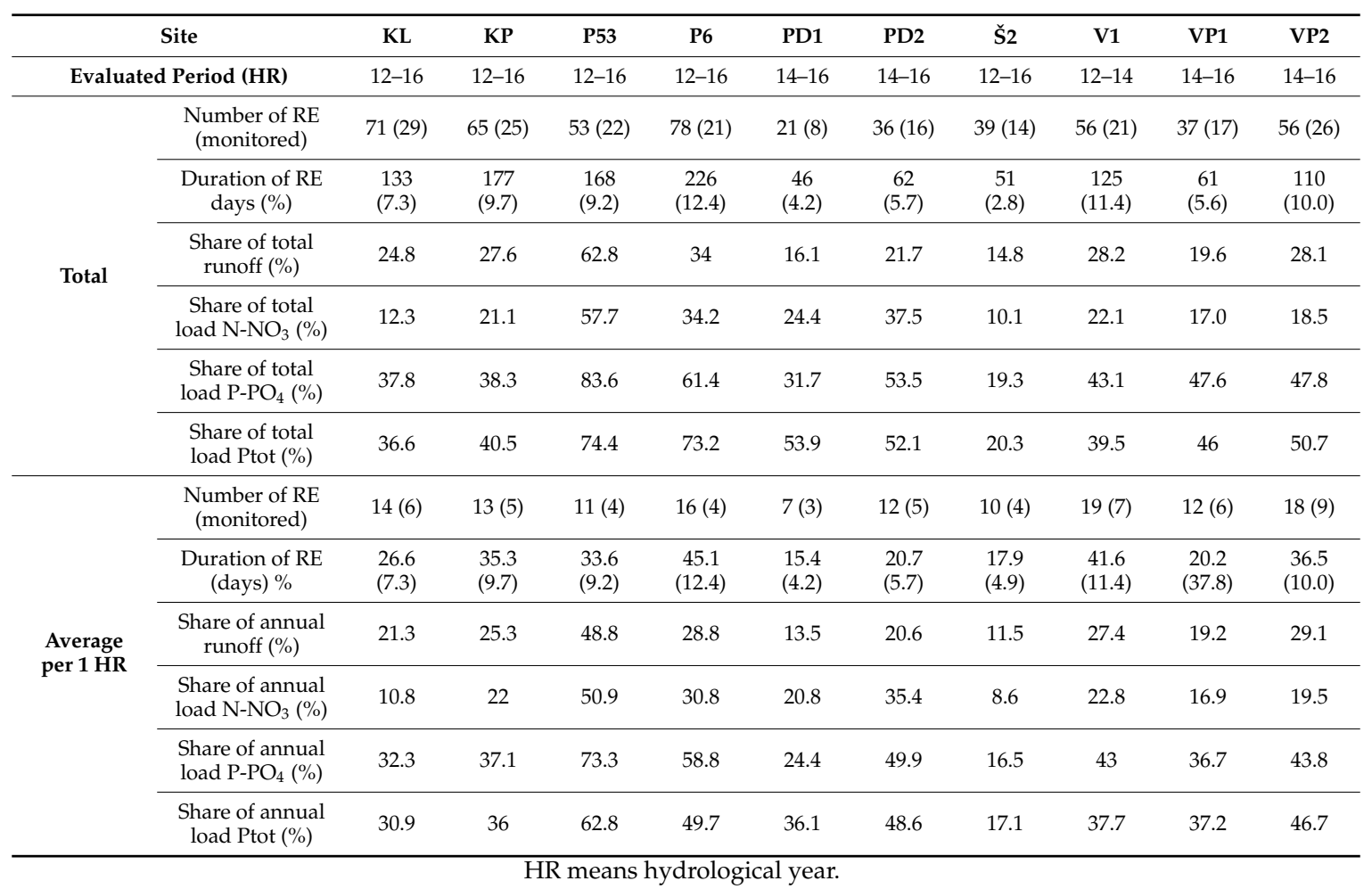

\subsection{Statistical Analyses and Comparison of Load Assessment Methods}

Basic statistics on drainage discharges as well as on $\mathrm{N}-\mathrm{NO}_{3}, \mathrm{P}_{-} \mathrm{PO}_{4}$, and $\mathrm{P}_{\text {tot }}$ concentration values were applied across all the sites, separately for regular and for event sampling schemes. Using both the monitored data and the semi-automated algorithm, the share of REs in the total drainage runoff was quantified. Further, the proportions of REs in the $\mathrm{N}-\mathrm{NO}_{3}, \mathrm{P}_{-} \mathrm{PO}_{4}$, and $\mathrm{P}_{\text {tot }}$ loads were calculated on an annual and a monthly basis. The comparison of the differences in the load assessment methods both for the annual (M1 to M5) and monthly (M3 to M5) loads was related to the true load method (M6). For the statistical significance of the differences among the methods on an annual basis, one-way ANOVA with a significance level of $\alpha=0.05$ was applied. Assumptions of the normal distribution of the data and the homogeneity of variances were checked, and, when they were not assumed to be satisfied, rank $\left(\mathrm{N}-\mathrm{NO}_{3}\right.$ and $\left.\mathrm{P}_{\text {tot }}\right)$ or square root transformations $\left(\mathrm{P}-\mathrm{PO}_{4}\right)$ were carried out. For a comparison of the differences between the selected load assessment methods (M3 to M6) on a monthly basis, root mean square error (RMSE) was used. RMSE expresses the cumulative degree of the relative error of a particular method, related to M6, when both accuracy and precision are taken into account [45]. Accuracy (E) was calculated as a ratio of M6 to M1 to M5 (Equation (8)), and precision was expressed by the standard deviation s of E. The RMSE was then calculated according to Equation (9).

$$
\begin{aligned}
E_{M 3, M 4, M 5} & =\frac{M 6}{M 3, M 4, M 5} \\
R M S E & =\sqrt{\overline{\mathrm{E}}^{2}+s^{2}}
\end{aligned}
$$




\section{Results}

\subsection{Dynamics of $N$ and $P$ Concentrations}

The concentration values of $\mathrm{N}-\mathrm{NO}_{3}, \mathrm{P}_{-} \mathrm{PO}_{4}$, and $\mathrm{P}_{\text {tot }}$ in drainage waters differed profoundly across the sites, between hydrological years, and within regular sampling (RS) and event sampling (ES) schemes. In RSs, $\mathrm{N}-\mathrm{NO}_{3}$ concentrations were 1.0 to $91.5 \mathrm{mg} / \mathrm{L}$ (median $19.4 \mathrm{mg} / \mathrm{L}$ ), $\mathrm{P}-\mathrm{PO}_{4}$ ranged between 0.001 and $0.424 \mathrm{mg} / \mathrm{L}$ (median $0.020 \mathrm{mg} / \mathrm{L}$ ), and concentrations of $P_{\text {tot }}$ were 0.001 to $0.747 \mathrm{mg} / \mathrm{L}$ (median $0.046 \mathrm{mg} / \mathrm{L}$ ). In the $\mathrm{ES}, \mathrm{N}-\mathrm{NO}_{3}$ concentrations were 0.452 to $144.9 \mathrm{mg} / \mathrm{L}$ (median $14.9 \mathrm{mg} / \mathrm{L}$ ), $\mathrm{P}_{-}-\mathrm{PO}_{4}$ ranged between 0.001 to $2.174 \mathrm{mg} / \mathrm{L}$ (median $0.043 \mathrm{mg} / \mathrm{L}$ ), and $\mathrm{P}_{\text {tot }}$ was between 0.001 to $3.231 \mathrm{mg} / \mathrm{L}$ (median $0.120 \mathrm{mg} / \mathrm{L}$ ).

The concentrations of nutrients adjusted to hydrology $(C f w)$ were usually lower for $\mathrm{N}-\mathrm{NO}_{3}$ in REs compared to RSs, whereas for both $\mathrm{P}_{-} \mathrm{PO}_{4}$ and $\mathrm{P}_{\text {tot }}$, the opposite was true. This means that during an $\mathrm{RE}$, a dilution of $\mathrm{N}-\mathrm{NO}_{3}$ in drainage waters usually prevailed, whilst for both $\mathrm{P}_{-} \mathrm{PO}_{4}$ and $\mathrm{P}_{\text {tot }}$, the concentrations usually rose with elevated discharge (Figure $4 \mathrm{a}-\mathrm{c}$ ). The only exceptions were sites PD1 and PD2, with $C f w$ N-NO 3 being higher in REs than in RSs. No statistically significant correlation between drainage discharge and any of the substances was discovered during baseflow conditions. During an RE, positive correlations between discharge and both P forms were found, although with a broad range of slopes and shapes of the regression curves (data not shown).

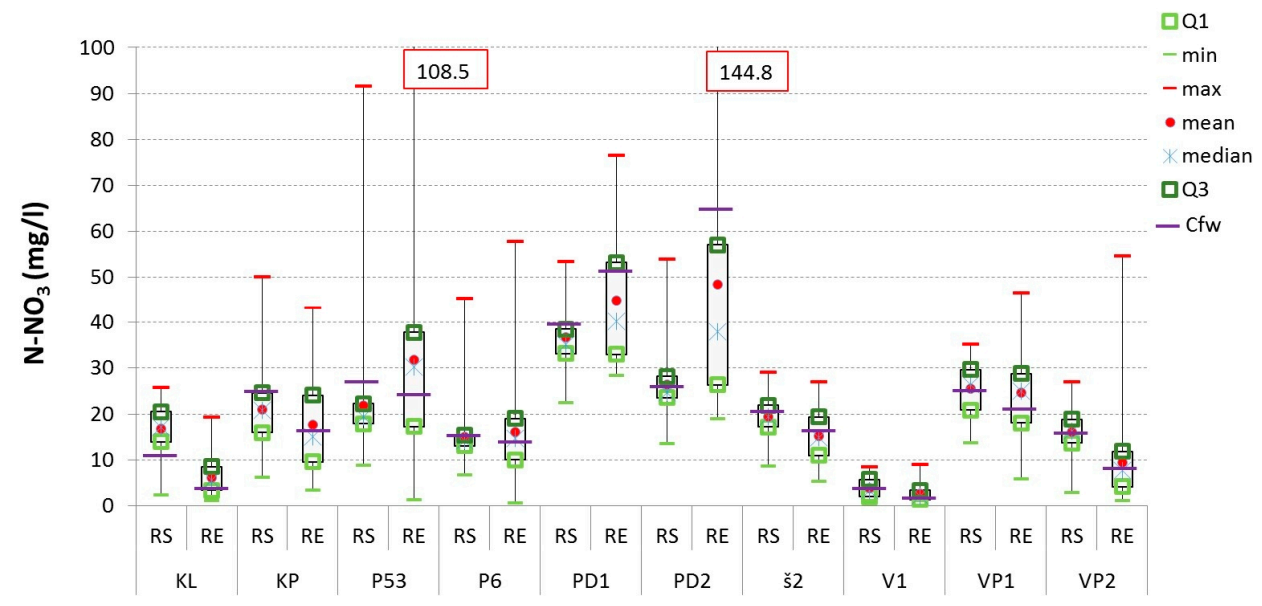

(a)

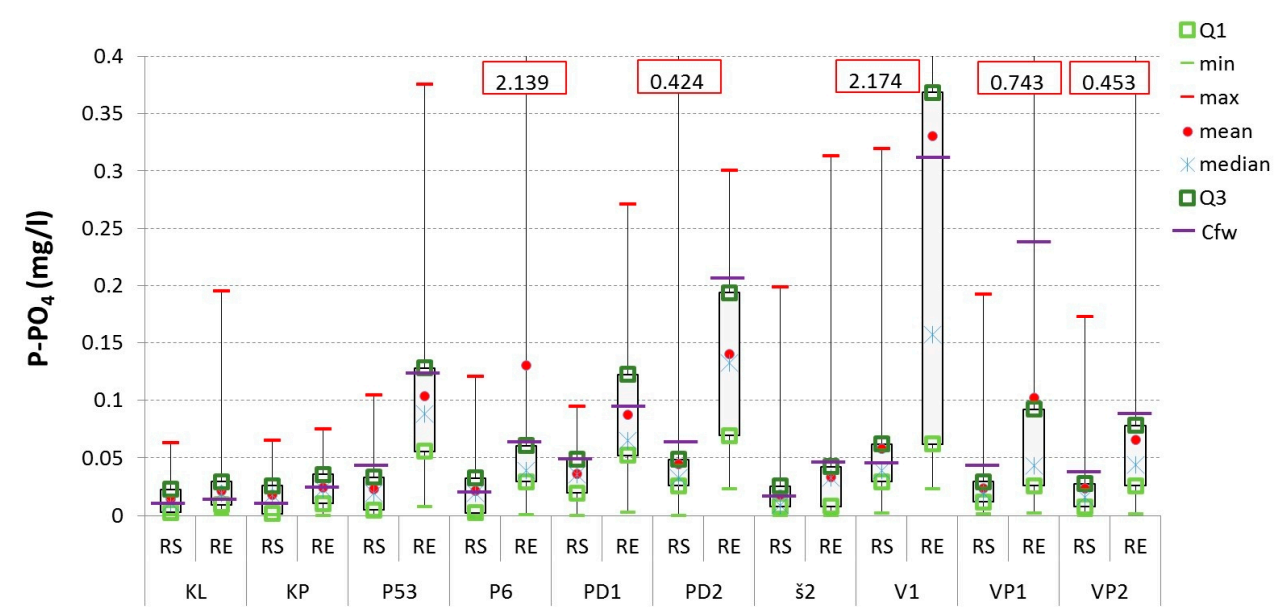

(b)

Figure 4. Cont. 


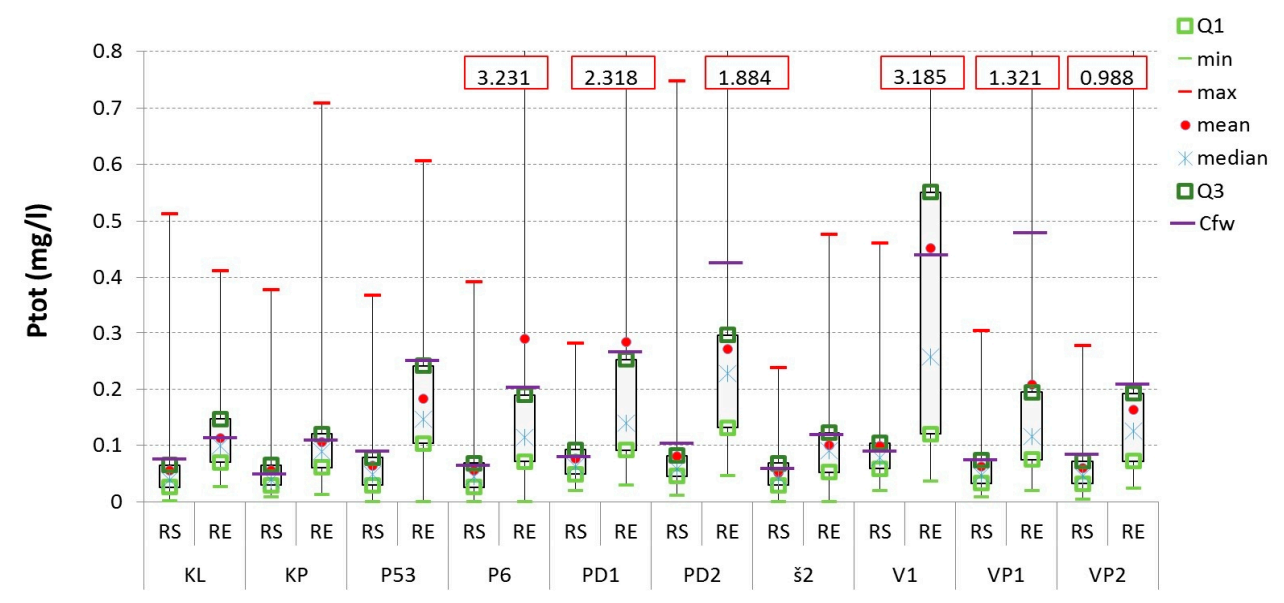

(c)

Figure 4. (a) Basic statistics of $\mathrm{N}^{-N_{3}}$ concentrations in drainage waters across all the monitored sites, for regular (RS) and event (RE) sampling schemes. Cfw is flow-weighed concentration; (b) Basic statistics of $\mathrm{P}_{-} \mathrm{PO}_{4}$ concentrations in drainage waters across all the monitored sites, for regular (RS) and event (RE) sampling schemes. Cfw is flow-weighed concentration; (c) Basic statistics of Ptot concentrations in drainage waters across all the monitored sites, for regular (RS) and event (RE) sampling schemes. Cfw is flow-weighed concentration.

\subsection{Runoff Events and Their Proportion in the Total Runoff, $N$ and P Loads}

The average number of REs per hydrological year, across all the sites during the whole monitored period, was 13 (2 to 25), and these lasted on average for 30 (5.3 to 81.3) days within a hydrological year; see Table 3. The portion of REs sampled in one season varied from $30 \%$ to $45 \%$ of the total number of REs (Table 3). The within-period differences among the number and magnitudes of REs were induced most probably by different precipitation amounts and their variable time-distribution across the evaluated period (hydrological years). The lowest number of REs was monitored in the very dry year 2015 (an RE lasted on average 14 days, with an average 12\% share on the total runoff), whereas in the wet year 2013, an RE lasted on average 48.5 days, with the mean share on the total runoff being $38.5 \%$. The proportion of REs in the annual total runoff and in the $\mathrm{N}-\mathrm{NO}_{3}, \mathrm{P}_{-} \mathrm{PO}_{4}$, and $\mathrm{P}_{\text {tot }}$ loads across all the monitored sites and periods was on average $24.5 \%(1.8-91.1 \%), 23.8 \%(1.7-85.5 \%)$, $41.6 \%(2.1-98.1 \%)$, and $40.3 \%$ (1.4-96.5\%), respectively; see Table 3 and Figure 5 for details.

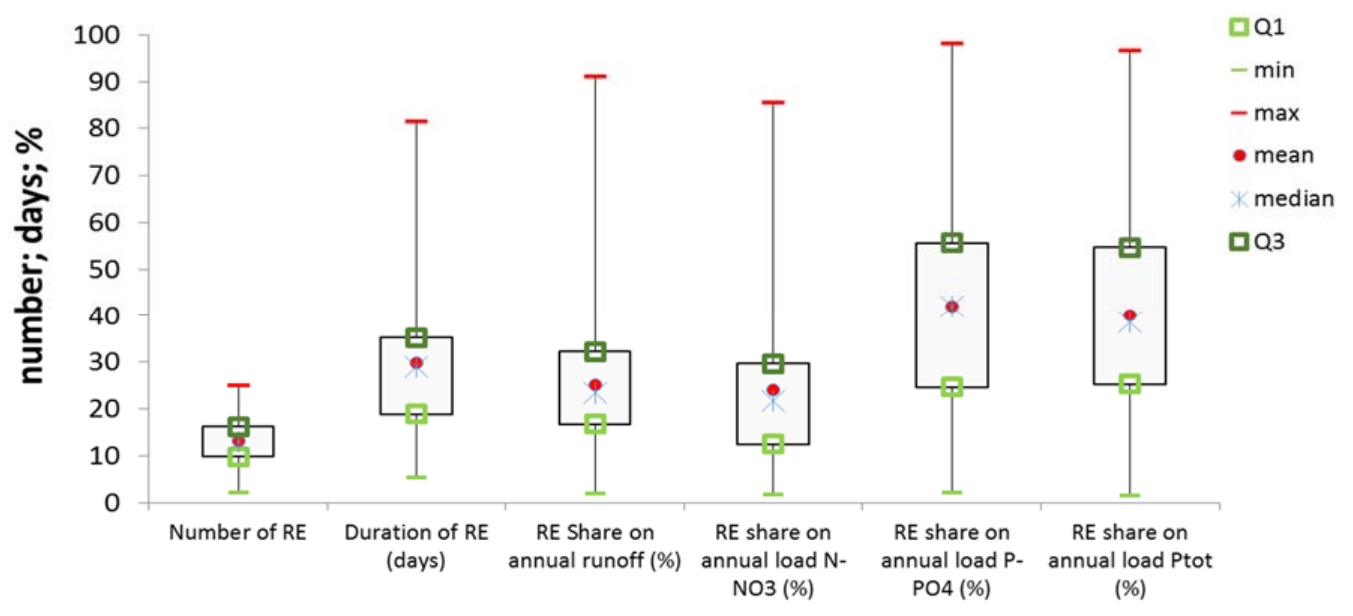

Figure 5. Basic statistics of the share of runoff events (RE) in the annual runoff and nutrient loads (data from all monitored sites and periods). 


\subsection{Comparison of Load Assessment Methods Annual Load Schemes}

The annual true loads (M6) for $\mathrm{N}-\mathrm{NO}_{3}, \mathrm{P}_{-} \mathrm{PO}_{4}$, and $\mathrm{P}_{\text {tot }}$ across all the monitored sites and periods were on average $19.01 \mathrm{~kg} \cdot \mathrm{ha}^{-1} \mathrm{y}^{-1}(0.39-60.50), 32.09 \mathrm{~g} \cdot \mathrm{ha}^{-1} \cdot \mathrm{y}^{-1}(0.64-131.85)$, and $99.28 \mathrm{~g} \cdot \mathrm{ha}^{-1} \cdot \mathrm{y}^{-1}$ (3.83-337.65), respectively. The lowest $\mathrm{N}-\mathrm{NO}_{3}$ loads were measured at the grassland sites (KL, V1) and at the ploughed $\mathrm{P} 53$ site, which exhibits an obvious episodic runoff pattern. The $\mathrm{N}^{-\mathrm{NO}_{3}}$ annual load from ploughed sites was on average around $30 \mathrm{~kg} \cdot \mathrm{ha}^{-1} \cdot \mathrm{y}^{-1}$. The $\mathrm{P}_{-} \mathrm{PO}_{4}$ and $\mathrm{P}_{\text {tot }}$ loads were comparable at the ploughed and grazed catchment (V1). The lowest $\mathrm{P}_{-} \mathrm{PO}_{4}$ and $\mathrm{P}_{\text {tot }}$ loads were measured at sites KL and P53, the catchments with the smallest total runoff.

The nutrient load assessment algorithms differed according to the employed method of discharge monitoring and, to a lesser extent, the method of nutrient concentration monitoring (calculation), with the exception of monitoring during the REs (M6). Nutrient loads, calculated by M1 to M5, in relation to M6, along with the loads in REs, are depicted on Figure 6a,b, and the basic statistics on M1 to M5 accuracy related to the true load (M6) on an annual basis for all the substances, sites, and monitored periods are shown in Table 4. For annual $\mathrm{N}^{-\mathrm{NO}_{3}}$ loads, $\mathrm{M} 1$ was the least accurate method, when accounting for the average 3.2\% underestimation ( -27.5 to $64.5 \%$ ) of the M6 load. The M1 algorithm was also the least accurate for annual phosphorus loads; for $\mathrm{P}_{-} \mathrm{PO}_{4}$, it underestimated M6 loads by $27.9 \%$ on average ( $-93.3 \%$ to $47.5 \%$ ), and, for $P_{\text {tot }}$, it underestimated M6 loads by $28.2 \%$ on average ( $-78.2 \%$ to $4.2 \%$ ). None of the variables (nutrient loads according to M1 to M6 across all the sites and monitored periods) was affected significantly by the methods (ANOVA; $p>0.05$ ).

\subsection{Monthly Load Schemes}

The monthly nutrient true loads (M6) for $\mathrm{N}-\mathrm{NO}_{3}, \mathrm{P}_{-} \mathrm{PO}_{4}$, and $\mathrm{P}_{\text {tot }}$ across all the monitored sites and periods were on average $1.52 \mathrm{~kg} \cdot \mathrm{ha}^{-1} \cdot \mathrm{month}^{-1}(0.01-16.41), 2.81 \mathrm{~g} \cdot \mathrm{ha}^{-1} \cdot \mathrm{month}^{-1}(0.003-48.85)$, and $6.87 \mathrm{~g} \cdot \mathrm{ha}^{-1} \cdot \mathrm{month}^{-1}(0.004-139.32)$, respectively. The accuracy and the RMSE of M3 to M5 (M1 and M2 only on annual basis) as related to the true loads (M6) are given in Tables 5 and 6, and the accuracy for all the sites over the monitored period is displayed in Figure 7a,b. In the monthly load schemes, the results showed that the algorithm that did not use a continuous record of discharge (M3) under- or overestimated nutrient loads the most. For $\mathrm{N}_{-} \mathrm{NO}_{3}$, the average underestimation by $\mathrm{M} 3$ on a monthly basis was $10.5 \%$, whereas for $\mathrm{P}_{-} \mathrm{PO}_{4}$ and $\mathrm{P}_{\text {tot }}$ it was $176 \%$ and $59 \%$, respectively. The extensive underestimation of monthly $\mathrm{P}_{-} \mathrm{PO}_{4}$ loads was due to the fact that, at some sites (P53, V1, VP1), the $\mathrm{P}_{-} \mathrm{PO}_{4}$ loss occurred solely during REs. As seen in Tables 5 and 6, M4 and M5 gave comparable results; i.e., for $\mathrm{N}-\mathrm{NO}_{3}$ loads, the underestimation was on average only around $3 \%$, for $\mathrm{P}^{-\mathrm{PO}_{4}}$ loads it was on average around $100 \%$ and for $\mathrm{P}_{\text {tot }}$ it was $35 \%$ to $40 \%$.

Table 4. Accuracy statistics (\%) of the M1 to M5 algorithms related to the true load (M6) on an annual basis for all the substances, sites, and monitored periods.

\begin{tabular}{|c|c|c|c|c|c|c|c|c|c|c|c|c|}
\hline & \multicolumn{4}{|c|}{$\mathrm{N}-\mathrm{NO}_{3}$} & \multicolumn{4}{|c|}{$\mathrm{P}_{-} \mathrm{PO}_{4}$} & \multicolumn{4}{|c|}{$P_{\text {tot }}$} \\
\hline & $\min$ & $\max$ & mean & median & $\min$ & $\max$ & mean & median & $\min$ & $\max$ & mean & median \\
\hline M1 & -27.5 & 64.5 & -3.2 & -6.9 & -93.3 & 47.5 & -27.9 & -27.8 & -78.2 & 4.2 & -28.2 & -23.6 \\
\hline M2 & -24.8 & 46.1 & 3.2 & 0.3 & -92.0 & 16.1 & -20.5 & -15.0 & -79.9 & 17.8 & -17.8 & -11.9 \\
\hline M3 & -48.7 & 74.1 & 1.3 & -2.8 & -79.5 & 89.4 & -18.8 & -22.2 & -80.9 & 34.1 & -18.2 & -12.7 \\
\hline M4 & -38.4 & 39.8 & 1.4 & 2.3 & -74.6 & 10.6 & -22.5 & -17.8 & -80.1 & 18.5 & -21.7 & -16.9 \\
\hline M5 & -37.3 & 41.7 & 1.4 & 2.1 & -74.7 & 6.0 & -24.6 & -18.7 & -79.7 & 20.5 & -21.9 & -14.5 \\
\hline
\end{tabular}


Table 5. Average monthly accuracy (\%) of the M3 to M5 algorithms related to the true load (M6) for all the substances, sites, and monitored periods.

\begin{tabular}{cccccccccc}
\hline & \multicolumn{3}{c}{$\mathbf{M 3}$} & \multicolumn{3}{c}{$\mathbf{M 4}$} & \multicolumn{3}{c}{$\mathbf{M 5}$} \\
\hline Site & $\mathbf{N - N O}_{3}$ & $\mathbf{P - P O}_{\mathbf{4}}$ & $\mathbf{P}_{\text {tot }}$ & $\mathbf{N - N \mathbf { N } _ { 3 }}$ & $\mathbf{P - P O}_{\mathbf{4}}$ & $\mathbf{P}_{\text {tot }}$ & $\mathbf{N - N \mathbf { O } _ { 3 }}$ & $\mathbf{P - P O}_{4}$ & $\mathbf{P}_{\text {tot }}$ \\
KL & 0.38 & -33.39 & -20.93 & 3.97 & -31.35 & -16.17 & 4.03 & -27.33 & -12.22 \\
KP & 1.91 & -37.20 & -12.48 & 2.17 & -39.78 & -12.66 & 2.48 & -37.35 & -12.63 \\
P53 & -12.35 & -962.19 & -88.09 & -8.58 & -445.31 & -51.30 & -21.91 & -473.09 & -59.06 \\
P6 & -2.80 & -145.51 & -96.26 & -2.42 & -140.96 & -88.37 & -0.65 & -126.26 & -75.83 \\
PD1 & -11.28 & -16.86 & -103.62 & -1.19 & -3.55 & -30.85 & -1.42 & -6.22 & -29.87 \\
PD2 & -38.87 & 0.29 & 8.41 & -14.62 & -33.72 & -37.27 & -14.42 & -35.68 & -37.38 \\
S2 & -16.39 & -88.88 & -41.40 & -5.39 & -29.36 & -31.66 & -0.36 & -21.95 & -13.80 \\
V1 & -6.60 & -211.20 & -92.73 & -0.60 & -155.40 & -63.18 & -0.20 & -141.39 & -41.51 \\
VP1 & -10.67 & -207.78 & -88.58 & -1.83 & -144.03 & -52.79 & -1.43 & -128.40 & -32.07 \\
VP2 & -7.72 & -60.50 & -53.11 & -0.88 & -36.21 & -30.14 & 3.22 & -39.77 & -29.97 \\
average & -10.44 & -176.32 & -58.88 & -2.94 & -105.97 & -41.44 & -3.07 & -103.74 & -34.43 \\
\hline
\end{tabular}

Table 6. Average monthly RMSE (\%) of the M3 to M5 algorithms related to the true load (M6) for all the substances, sites, and monitored periods.

\begin{tabular}{|c|c|c|c|c|c|c|c|c|c|}
\hline \multirow[b]{2}{*}{ Site } & \multicolumn{3}{|c|}{ M3 } & \multicolumn{3}{|c|}{ M4 } & \multicolumn{3}{|c|}{ M5 } \\
\hline & $\mathrm{N}-\mathrm{NO}_{3}$ & $\mathrm{P}_{-} \mathrm{PO}_{4}$ & $P_{\text {tot }}$ & $\mathrm{N}-\mathrm{NO}_{3}$ & $\mathrm{P}_{-} \mathrm{PO}_{4}$ & $P_{\text {tot }}$ & $\mathrm{N}-\mathrm{NO}_{3}$ & $\mathrm{P}_{-} \mathrm{PO}_{4}$ & $P_{\text {tot }}$ \\
\hline KL & 23.58 & 90.87 & 61.16 & 9.98 & 81.77 & 37.59 & 8.90 & 77.27 & 26.96 \\
\hline $\mathrm{KP}$ & 21.90 & 97.37 & 43.44 & 9.08 & 92.38 & 28.94 & 8.49 & 85.34 & 28.47 \\
\hline P53 & 61.15 & 4126.42 & 278.01 & 63.97 & 1596.52 & 123.47 & 175.61 & 1841.11 & 177.04 \\
\hline P6 & 24.43 & 382.84 & 288.40 & 13.28 & 343.94 & 259.29 & 10.92 & 329.51 & 224.72 \\
\hline PD1 & 60.91 & 91.76 & 579.89 & 8.96 & 25.68 & 155.82 & 7.29 & 16.13 & 148.69 \\
\hline PD2 & 140.71 & 50.32 & 43.11 & 35.40 & 84.58 & 86.69 & 34.43 & 77.05 & 85.87 \\
\hline Š2 & 59.11 & 276.52 & 124.46 & 49.25 & 91.19 & 89.28 & 15.62 & 53.71 & 36.59 \\
\hline V1 & 35.33 & 826.37 & 250.02 & 14.25 & 631.76 & 142.17 & 10.92 & 565.58 & 76.86 \\
\hline VP1 & 29.96 & 827.53 & 255.65 & 6.56 & 631.46 & 144.63 & 4.81 & 565.06 & 79.65 \\
\hline VP2 & 29.33 & 125.70 & 129.90 & 19.15 & 74.43 & 75.60 & 17.24 & 76.72 & 62.68 \\
\hline mean & 48.64 & 689.57 & 205.40 & 22.99 & 365.37 & 114.35 & 29.42 & 368.75 & 94.75 \\
\hline
\end{tabular}

\section{Discussion}

\subsection{Dynamics of $N$ and $P$ Concentrations}

In general, the grassed catchments $(\mathrm{KL}, \mathrm{V} 1)$ had lower $\mathrm{N}-\mathrm{NO}_{3}$ concentration values than the ploughed catchments, both during RSs and ESs due to the well-known mitigation effect of grassland on nitrate leaching $[12,15,42]$. For both $\mathrm{P}$ forms monitored in drainage waters, no such differences were found. During the REs, a dilution of $\mathrm{N}^{-\mathrm{NO}_{3}}$ in drainage waters usually prevailed, whilst for both $\mathrm{P}_{-} \mathrm{PO}_{4}$ and $\mathrm{P}_{\text {tot }}$, the concentrations usually rose with elevated discharge, which is in accordance with many monitoring campaigns in tile-drained catchments $[5,12,18,25,31]$. The only exceptions were sites PD1 and PD2, with $C f w$ N-NO 3 higher in ESs than in RSs. This was most probably due to the over-fertilization of these catchments either by mineral nitrogen or digestate, as documented by other studies $[13,44]$.

\subsection{Runoff Events and Their Proportion on Total Runoff, $N$ and P Loads}

The within-site differences between the number and magnitudes of REs and their share of total runoff and between the $\mathrm{N}-\mathrm{NO}_{3}, \mathrm{P}_{-} \mathrm{PO}_{4}$, and $\mathrm{P}_{\text {tot }}$ loads were brought about most probably by the distinct hydrological connectivity and runoff formation pattern in particular drainage-catchment systems $[7,21,34,46]$. This connectivity is affected by the position of a drainage system in a particular part of a slope (higher, lower) and by local soil variability [42,43,47-49]. This can lead to different proportions of runoff components in drainage runoff, e.g., sites lying in higher positions on slopes 
(typically P53) have lower proportions of baseflow and higher numbers of REs. Similar (very variable) proportions of event water (12\% to 50\%) for similar amounts of precipitation (20 to $30 \mathrm{~mm}$ ) are reported by other studies [21,50-52]. This variability in REs is more probably caused by diverse hydrological conditions in the catchments preceding the rain, namely, soil moisture, the groundwater level in summer, and snow cover for winter events, than by the intensity of rainfall [51], although some other studies reported contrarily [21,53].

In general, the relatively small share of REs for $\mathrm{N}^{-\mathrm{NO}_{3}}$ loads is explained as a dilution of nitrate-rich drainage water by rain water during the majority of the REs, both on grassed as well as on ploughed sites, as discovered also by other studies $[4,17,44]$. The highest share of REs in $\mathrm{N}-\mathrm{NO}_{3}$ loads was measured in the N-overfertilized catchments (PD1, PD2; RE share up to $61 \%$ ) and at site P53 (RE share on average 51\%), which had a profound episodic runoff pattern (some months were almost without regular flow). The low share of REs for $\mathrm{N}^{-\mathrm{NO}_{3}}$ loads was exhibited on grassed site $\mathrm{KL}$ (on average $10.8 \%$ ) and on ploughed site Š2 (on average $8.6 \%$ ), which corresponded to a high baseflow. For both P forms, higher proportions of REs for P loads were found. The higher share of RE on P loads compared to $\mathrm{N}$ loads was caused by the well documented different patterns of $\mathrm{N}$ and $\mathrm{P}$ leaching from soil into drainage waters [10,34], when P concentrations substantially rose with the elevated discharge across all the sites. This manifested the most at the sites with a substantial share of REs in the runoff (P53 site). However, a detailed analysis of these effects was not an aim of this study.

\subsection{Comparison of Load Assessment Methods}

The lowest $\mathrm{P}-\mathrm{PO}_{4}$ and $\mathrm{P}_{\text {tot }}$ loads were measured at the sites with the smallest total runoff (KL, P53). This means that, for both the $\mathrm{P}_{-} \mathrm{PO}_{4}$ and $\mathrm{P}_{\text {tot }}$ loads, the runoff pattern seems to play in general a more dominant role than land use within the monitored catchments, as discovered also by other studies in similar and different climate and cropping systems $[5,9,12,19]$. The differences in total runoff in sites with similar geographical conditions were caused most probably by the different areas of their recharge zones [43]. The changeable runoff pattern probably also explains the fact that the ANOVA found the differences among the methods to be insignificant $\left(\mathrm{N}^{-\mathrm{NO}_{3}}\right.$ : F-ratio 0.08 ,

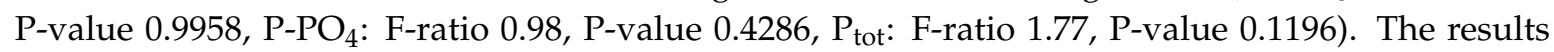
showed supposedly small differences between the methods on the annual basis. M2 appeared to be quite a reasonable algorithm for the assessment of $\mathrm{N}^{-\mathrm{NO}_{3}}$ loads, when only grab sampling (without continuous monitoring of discharge) was employed. However, it still gave large underestimations, especially for both phosphorus compounds, as the grab sampling rarely captured different REs with different $\mathrm{P}$ concentration values, as documented by [31-34].

For monthly nutrient loads, the M5 algorithm, with continuous flow measurements and using linear interpolations of the concentrations from the consecutively sampled days, resulted in a quite acceptable degree of accuracy for monthly $\mathrm{N}$ load estimation, with an exception for one overfertilized site (PD2) and site P53, which had a dominant episodic runoff pattern, where the average underestimation of $\mathrm{N}$ loads was $14.5 \%$ and $21.9 \%$, respectively. M5, however, for both $\mathrm{P}$ compounds, gave unsatisfactory estimates of the monthly loads since the temporal changes of $\mathrm{P}$ concentrations were not covered by the regular sampling, as discovered in other studies when a weekly time step of sampling was employed $[18,33,34]$.

The results have highlighted the importance of runoff events (not only erosion-generating) in delivering phosphorus by tile drainage, sometimes in large amounts. Given that the average duration of an RE within a hydrological year was 30 (5.3 to 81.3) days across all the sites and seasons, the loss of phosphorus by subsurface runoff should be given considerable attention in central European tile-drained catchments, as recommended by many other studies in tile-drained landscapes of diverse natural and agricultural characteristics $[5,6,8,10,34,35]$. Since the algorithms that do not use a continuous record of flow rates (M1 to M3) has considerable poorer performance, yielding biased and imprecise results, the use of continuous flow measurement is necessary to capture 
discharge dynamics and to calculate the real nutrient fluxes from small tile-drained catchments with reasonable certainty $[25,27,33]$.

The RMSE expressed the cumulative information on the degree and variation of the relative error of a particular method, relative to M6, when both accuracy and precision were taken into account. It clearly showed that, for monthly $\mathrm{N}$ load estimation, $\mathrm{M} 3 \mathrm{had}$ an average RMSE approximately two-fold greater than those of M4 and M5 (48.6\%, 23\%, 29.4\%, respectively). For P, roughly the same ratio was discovered, although in terms of percent values in the hundreds (Table 6). As for the accuracy, for the RMSE, the largest degrees and variations of errors were found for the sites with significant episodic runoff patterns, especially for $\mathrm{P}_{-} \mathrm{PO}_{4}$ loss.
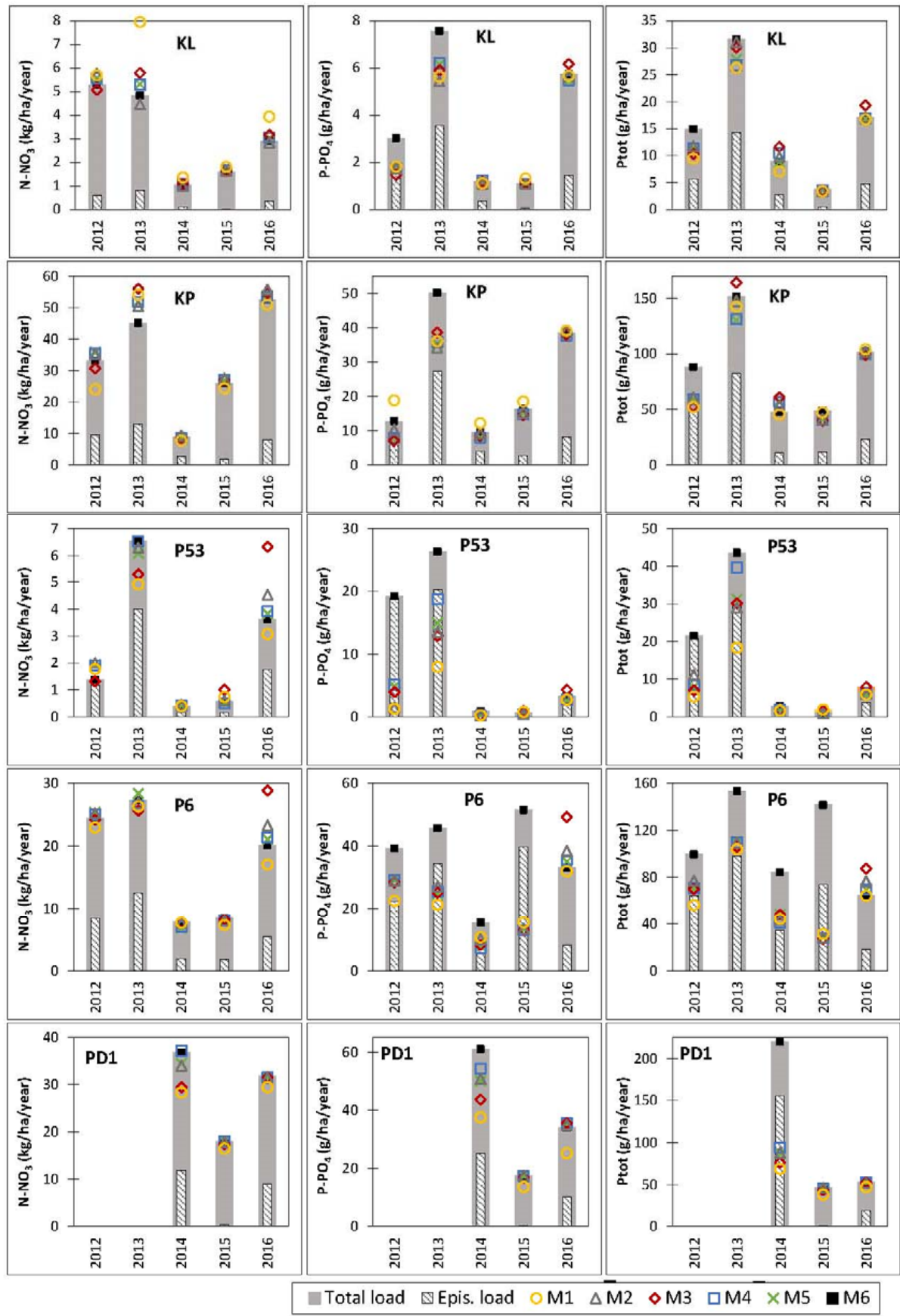

(a)

Figure 6. Cont. 

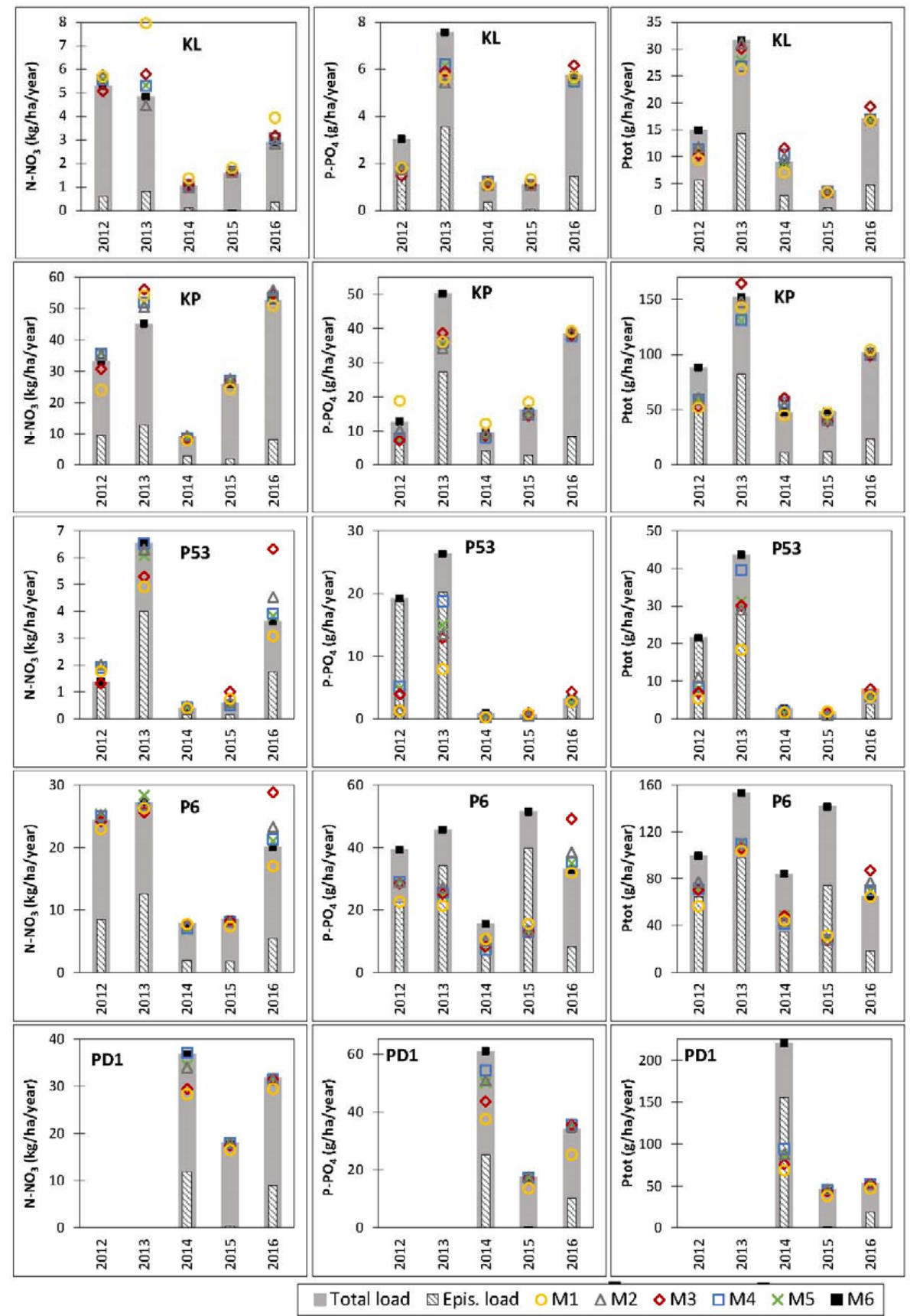

(b)

Figure 6. (a) Annual nutrient loads calculated by M1 to M6 and the proportion of runoff events in the total load for all substances at sites KL, KP, P53, P6, and PD1 and for all monitored periods. (b) Annual nutrient loads calculated by M1 to M6 and the proportion of runoff events in the total load for all substances at sites PD2, Š2, V1, VP1, and VP2 and for all monitored periods. 


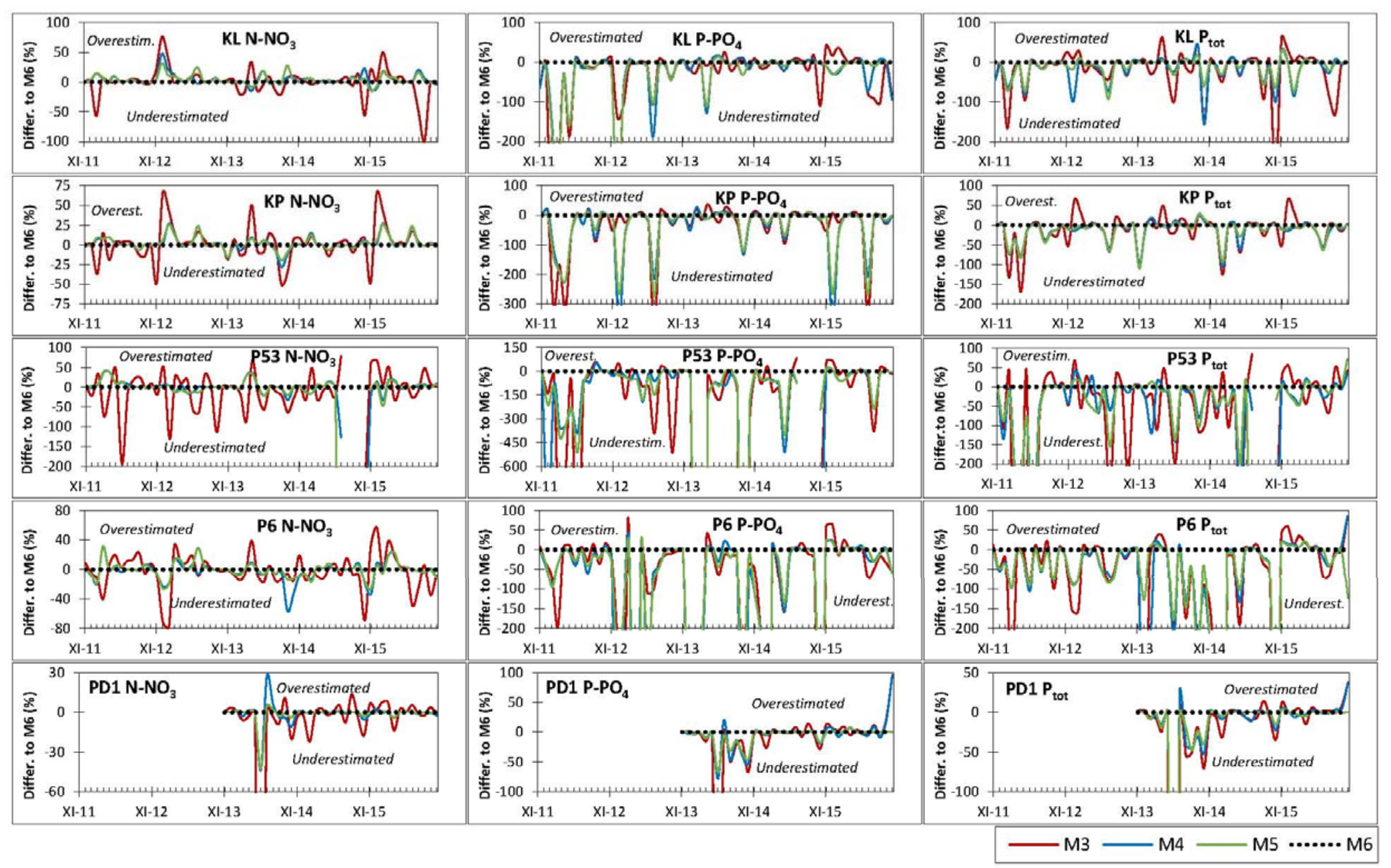

(a)

Figure 7. Cont. 


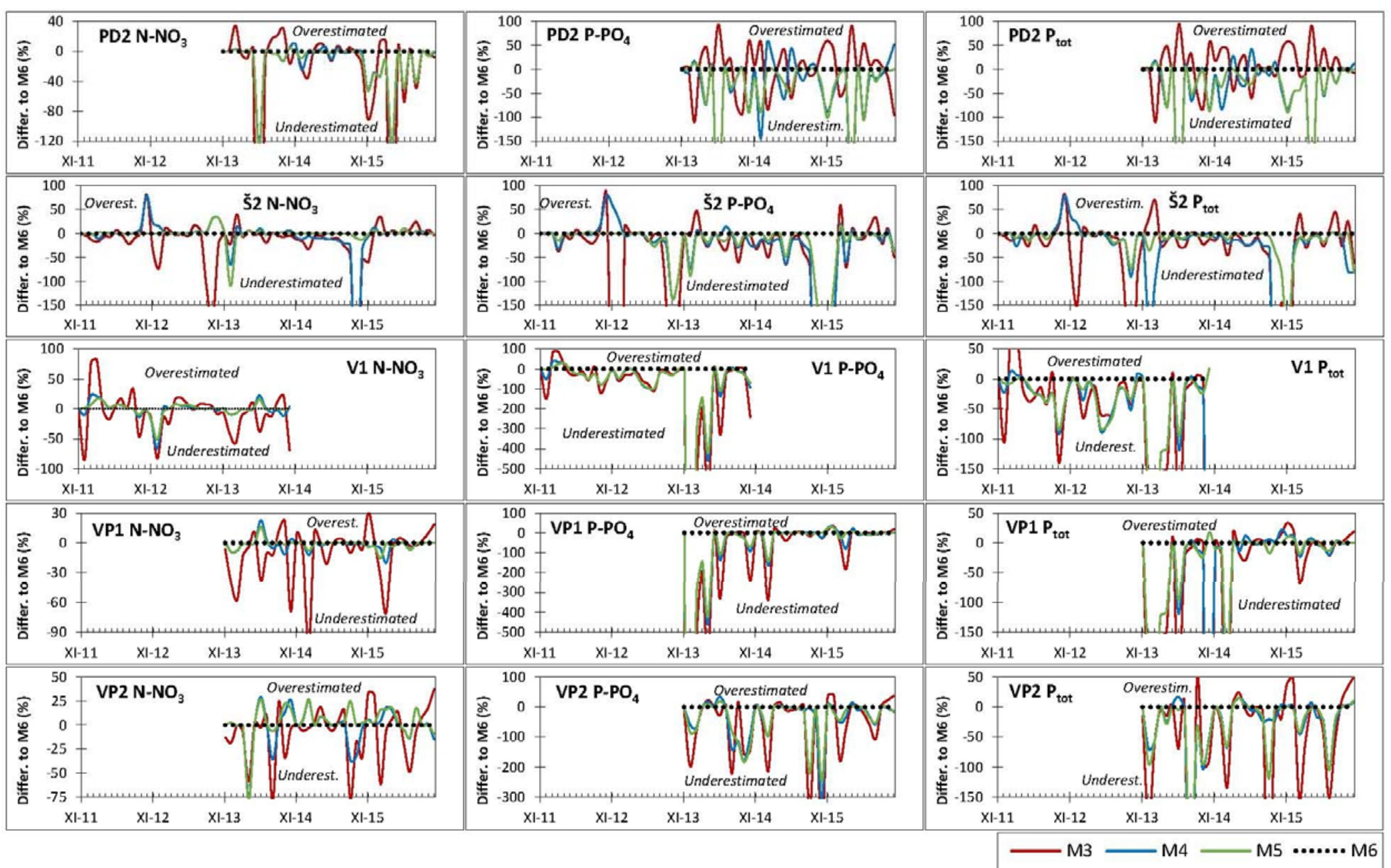

(b)

Figure 7. (a) Monthly values of accuracy (\%) of M3 to M5 related to M6 for all substances at sites KL, KP, P53, P6, and PD1 and for all monitored periods. (b) Monthly values of accuracy (\%) of M3 to M5 related to M6 for all substances at sites PD2, Š2, V1, VP1, and VP2 and for all monitored periods. 


\section{Conclusions}

This study compared six methods for nitrogen and phosphorus load calculation in ten small tile-drained sloped catchments in both annual and monthly time steps based on data from three to five hydrological years. Further, for the monitored sites and periods, the share of runoff events in the total runoff of ${\mathrm{N}-\mathrm{NO}_{3}}_{3}, \mathrm{P}_{-} \mathrm{PO}_{4}$, and $\mathrm{P}_{\text {tot }}$ was quantified. A novel semi-automated algorithm for the identification and selection of runoff events from continuous flow using drainage water temperature was proposed and applied for load calculation in the unsampled events. The share of runoff events in $\mathrm{N}$ loads was on average $5 \%$ to $30 \%$ of the total annual load, whereas for P (dissolved and total), the share of runoff events was on average $10 \%$ to $80 \%$ of the total annual load. The most precise methods for nutrient load estimation were those with the use of continuous measurement of the discharge (M4, M5). However, without sampling the runoff events, these methods showed considerable uncertainties, especially for phosphorus load estimation. The methods based on point monitoring discharge and water quality (M1 to M3), commonly employed in practice when balancing non-point pollution sources in small tile-drained agricultural catchments, underestimated the annual loads of $\mathrm{N}$ by $10 \%$ to $20 \%$ and of $\mathrm{P}$ by $30 \%$ to $80 \%$. For the monthly loads, this study demonstrated that methods without continuous flow measurements and with infrequent sampling tended to underestimate $\mathrm{N}$ and especially $\mathrm{P}$ loads by percentage values in the tens to the hundreds. The variability in loads between the years and sites was caused most probably by the dissimilar runoff patterns between particular sites and between particular years, which is not captured by grab sampling and regular monitoring at fixed intervals.

Based on the acquired results, we recommend continuous flow and water temperature monitoring, as well as event-based sampling programmes, to be employed on tile drainage outlets, drainage mahnoles, or ditches. Although such very small catchments as observed in the present study could hardly be the subject of routine (nation-wide or large catchment) monitoring programmes, we emphasize the need to pay increased attention to the hydrochemical role of tile drainage since these systems strongly impact water quality and quantity in agriculturally exploited headwater catchments. This work also provided regionally representative $\mathrm{N}$ and $\mathrm{P}$ loads, which we consider to be of great value when balancing the non-point pollution sources of small water courses and designing appropriate mitigation measures for tile-drained land. Future work could focus on the linkages between catchment characteristics, nutrient load dynamics, and load calculation uncertainties provided by different methods in different seasons. Further, a more detailed hydrological description of the sites such as runoff flashiness, baseflow index, antecedent moisture conditions, or water catchment residence time will be employed in a follow-up study in order to better explain the magnitude of uncertainty and the dynamics of various algorithms across different catchments [27,34,46,47].

Acknowledgments: The research leading to these results has received funding from the Norwegian Financial Mechanism 2009 to 2014 under Project Contract no. 7F14341, 'Assessing water quality improvement options concerning nutrient and pharmaceutical contaminants in rural watersheds'. The project funds covered the costs of publishing this article in open access. The data and results introduced in this study were obtained from the projects of Technology Agency of the Czech Republic, No. TA03020202 and TA02020337. The Institutional support from Ministry of Agriculture No. RO0216 is also greatly acknowledged. The authors thank David Šádek, Hana Libichová, and Pavel Pražák for their field work and basic data management. The authors thank the anonymous reviewers for their very valuable comments. The authors dedicate this paper to František Doležal, a genuine expert in hydrology and soil science and an inspiring, open minded, and favourite colleague.

Author Contributions: Petr Fučík, Antonín Zajíček, and Renata Duffková conceived and designed the experiments; Antonín Zajíček, Jana Peterková, Petr Fučík, Renata Duffková, and Markéta Kaplická performed the experiments; Antonín Zajíček, Markéta Kaplická, Petr Fučík, Renata Duffková, Jana Peterková, and Jana Maxová analyzed the data; and Petr Fučík, Antonín Zajíček, Markéta Kaplická, Renata Duffková, and Šárka Takáčová wrote the paper. Authorship is limited to those who have contributed substantially to the work reported.

Conflicts of Interest: The authors declare no conflicts of interest. The founding sponsors had no role in the design of the study; in the collection, analyses, or interpretation of data; in the writing of the manuscript; or in the decision to publish the results. 


\section{References}

1. Rogger, M.; Agnoletti, M.; Alaoui, A.; Bathurst, J.C.; Bodner, G.; Borga, M.; Chaplot, V.; Gallart, F.; Glatzel, G.; Hall, J.; et al. Land use change impacts on floods at the catchment scale: Challenges and opportunities for future research. Water Resour. Res. 2017, 53. [CrossRef]

2. Van Geer, F.C.; Kronvang, B.; Broers, H.P. High-resolution monitoring of nutrients in groundwater and surface waters: process understanding, quantification of loads and concentrations, and management applications. Hydrol. Earth Syst. Sci. 2016, 20, 3619-3629. [CrossRef]

3. Dragon, K.; Kasztelan, D.; Gorski, J.; Najman, J. Influence of subsurface drainage systems on nitrate pollution of water supply aquifer (Tursko well-field, Poland). Environ Earth Sci. 2016, 75. [CrossRef]

4. Fučík, P.; Hejduk, T.; Peterková, J. Quantifying Water Pollution Sources in a Small Tile-drained Agricultural Watershed. CLEAN 2014, 42, 698-709. [CrossRef]

5. $\quad$ King, K.W.; Williams, M.R.; Macrae, M.L.; Fausey, N.R.; Frankenberger, J.; Smith, D.R.; Kleinman, P.J.A.; Brown, L.C. Phosphorus Transport in Agricultural Subsurface Drainage: A Review. J. Environ. Qual. 2015. [CrossRef] [PubMed]

6. Kyllmar, K.; Bechmann, M.; Deelstra, J.; Iital, A.; Blicher-Mathiesen, G.; Jansons, V.; Koskiaho, J.; Povilaitis, A. Long-term monitoring of nutrient losses from agricultural catchments in the Nordic-Baltic region-A discussion of methods, uncertainties and future needs. Agric. Ecosyst. Environ. 2014, 198, 4-12. [CrossRef]

7. Macrae, M. L.; English, M.C.; Schiff, S.L.; Stone, M. Capturing temporal variability for estimates of annual hydrochemical export from a first-order agricultural catchment in southern Ontario, Canada. Hydrol. Process. 2007, 21, 1651-1663. [CrossRef]

8. Rozemeijer, J.C.; Visser, A.; Borren, W.; Winegram, M.; van der Velde, Y.; Klein, J.; Broers, H.P. High-frequency monitoring of water fluxes and nutrient loads to assess the effects of controlled drainage on water storage and nutrient transport. Hydrol. Earth Syst. Sci. 2016, 20, 347-358. [CrossRef]

9. Smith, D.R.; King, K.W.; Johnson, L.; Francesconi, W.; Richards, P.; Baker, D.; Sharpley, A.N. Surface Runoff and Tile Drainage Transport of Phosphorus in the Midwestern United States. J. Environ. Qual. 2015, 44, 495-502. [CrossRef] [PubMed]

10. Christianson, L.E.; Harmel, R.D.; Smith, D.; Williams, M.R.; King, K. Assessment and Synthesis of 50 Years of Published Drainage Phosphorus Losses. J. Environ. Qual. 2016, 45, 1467-1477. [CrossRef] [PubMed]

11. Ernstsen, V.; Olsen, P.; Rosenbom, A.E. Long-term monitoring of nitrate transport to drainage from three agricultural clayey till fields. Hydrol. Earth Syst. Sci. 2015, 19, 3475-3488. [CrossRef]

12. King, K.W.; Williams, M.R.; Fausey, N.R. Effect of crop type and season on nutrient leaching to tile drainage under a corn-soybean rotation. J. Soil Water Conserv. 2016, 71, 56-68. [CrossRef]

13. Zhao, X.; Christianson, L.E.; Harmel, D.; Pittelkow, C.M. Assessment of drainage nitrogen losses on a yield-scaled basis. Field Crop. Res. 2016, 199, 156-166. [CrossRef]

14. Exner-Kittridge, M.; Strauss, P.; Blöschl, G.; Eder, A.; Saracevic, E.; Zessner, M. The seasonal dynamics of the stream sources and input flow paths of water and nitrogen of an Austrian headwater agricultural catchment. Sci. Total Environ. 2016, 542, 935-945. [CrossRef] [PubMed]

15. Fučík, P.; Zajíček, A.; Duffková, R.; Kvítek, T. Water Quality of Agricultural Drainage Systems in the Czech Republic-Options for Its Improvement. In Research and Practices in Water Quality; Lee, T.S., Ed.; InTech: Rijeka, Croatia, 2015; pp. 239-262. ISBN 978-953-51-2163-3.

16. Monaghan, R.M.; Smith, L.C.; Muirhead, R.W. Pathways of contaminant transfers to water from an artificially-drained soil under intensive grazing by dairy cows. Agric. Ecosyst. Environ. 2016, 220, 76-88. [CrossRef]

17. Zajíček, A.; Pomije, T.; Kvítek, T. Event water detection in tile drainage runoff using stable isotopes and a water temperature in small agricultural catchment in Bohemian-Moravian Highlands, Czech Republic. Environ. Earth Sci. 2016, 75. [CrossRef]

18. Tiemeyer, B.; Kahle, P.; Lennartz, B. Designing monitoring programs for artificially drained catchments. Vadose Zone J. 2010, 9, 14-24. [CrossRef]

19. Ulén, B.; von Brömssen, C.; Johansson, G.; Torstensson, G.; Forsberg, L.S. Trends in nutrient concentrations in drainage water from single fields under ordinary cultivation. Agric. Ecosyst. Environ. 2012, 161, 61-69. [CrossRef] 
20. Verma, S.; Markus, M.; Cooke, R.A. Development of error correction techniques for nitrate-N load estimation methods. J. Hydrol. 2012, 432, 12-25. [CrossRef]

21. Vidon, P.; Hubbard, H.; Cuadra, P.E.; Hennessy, M. Storm Flow Generation in Artificially Drained Landscapes of the US Midwest: Matrix Flow, Macropore Flow, or Overland Flow. Water 2012, 4, 90-111.

22. Kulhavý, Z.; Fučík, P. Adaptation Options for Land Drainage Systems Towards Sustainable Agriculture and the Environment: A Czech Perspective. Pol. J. Environ. Stud. 2015, 24, 1085-1102. [CrossRef]

23. Tlapáková, L.; Žaloudík, J.; Kolejka, J. Thematic survey of subsurface drainage systems in the Czech Republic. J. Maps 2016, 13, 55-65. [CrossRef]

24. Aulenbach, B.T.; Burns, D.A.; Shanley, J.B.; Yanai, R.D.; Bae, K.; Wild, A.D.; Yang, Y.; Yi, D. Approaches to stream solute load estimation for solutes with varying dynamics from five diverse small watersheds. Ecosphere 2016, 7. [CrossRef]

25. Birgand, F.; Faucheux, C.; Gruau, G.; Augeard, B.; Moatar, F.; Bordenave, P. Uncertainties in assessing annual nitrate loads and concentration indicators: Part 1: Impact of sampling frequency and load estimation algorithms. ASABE 2010, 53, 437-446. [CrossRef]

26. Harmel, R.D.; Smith, D.R.; King, K.W.; Slade, R.M. Estimating storm discharge and water quality data uncertainty: A software tool for monitoring and modeling applications. Environ. Model. Softw. 2009, 24, 832-842. [CrossRef]

27. Jiang, Y.; Frankenberger, J.R.; Bowling, L.C.; Sun, Z. Quantification of uncertainty in estimated nitrate-N loads in agricultural watersheds. J. Hydrol. 2014, 519, 106-116. [CrossRef]

28. Reynolds, K.N.; Loecke, T.D.; Burgin, A.J.; Davis, C.A.; Riveros-Iregui, D.; Thomas, S.A.; Clair, M.A.St.; Ward, A.S. Optimizing Sampling Strategies for Riverine Nitrate Using High-Frequency Data in Agricultural Watersheds. Environ. Sci. Technol. 2016. [CrossRef] [PubMed]

29. Richards, R.P.; Baker, D.B.; Kramer, J.W.; Ewing, D.E.; Merryfield, B.J.; Miller, N.L. Storm discharge, loads, and average concentrations in Northwest Ohio Rivers, 1975-1995. J. Am. Water Resour. Assoc. 2001, 37, 423-438. [CrossRef]

30. Guo, Y.; Markus, M.; Demissie, M. Uncertainty of nitrate-N load computations for agricultural watersheds. Water Resour. Res. 2002, 38, 1185. [CrossRef]

31. Williams, M.R.; King, K.W.; Macrae, M.L.; Ford, W.; Van Esbroeck, Ch.; Brunke, R.I.; English, M.C.; Schiff, S.L. Uncertainty in nutrient loads from tile-drained landscapes: Effect of sampling frequency, calculation algorithm, and compositing strategy. J. Hydrol. 2015, 530, 306-316. [CrossRef]

32. Cassidy, R.; Jordan, P. Limitations of instantaneous water quality sampling in surface-water catchments: Comparison with near-continuous phosphorus time-series data. J.Hydrol. 2011, 405, 182-193. [CrossRef]

33. Defew, L.H.; May, L.; Heal, K.V. Uncertainties in estimated phosphorus loads as a function of different sampling frequencies and common calculation methods. Mar. Freshwater. Res. 2013, 64, 373-386. [CrossRef]

34. Lam, W.V.; Macrae, M.L.; English, M.C.; O’Halloran, I.P.; Plach, J.M.; Wang, Y. Seasonal and event-based drivers of runoff and phosphorus export through agricultural tile drains under sandy loam soil in a cool temperate region. Hydrol. Process. 2016, 30, 2644-2656. [CrossRef]

35. Campbell, J.M.; Jordan, P.; Arnscheidt, J. Using high-resolution phosphorus data to investigate mitigation measures in headwater river catchments. Hydrol. Earth Syst. Sci. 2015, 19, 453-464. [CrossRef]

36. Bloodworth, J.W.; Holman, I.P.; Burgess, P.J.; Gillman, S.; Frogbrook, Z.; Brown, P. Developing a multi-pollutant conceptual framework for the selection and targeting of interventions in water industry catchment management schemes. J. Environ. Manag. 2015, 161, 153-162. [CrossRef] [PubMed]

37. Knauer, K. Pesticides in surface waters: A comparison with regulatory acceptable concentrations (RACs) determined in the authorization process and consideration for regulation. Environ. Sci. Eur. 2016, 28. [CrossRef] [PubMed]

38. Brauer, N.; O'Geen, A.T.; Dahlgren, R.A. Temporal variability in water quality of agricultural tailwaters: Implications for water quality monitoring. Agric. Water Manag. 2009, 96, 1001-1009. [CrossRef]

39. Lenhart, C.; Gordon, B.; Gamble, J.; Current, D.; Ross, N.; Herring, L.; Nieber, J.; Peterson, H. Design and Hydrologic Performance of a Tile Drainage Treatment Wetland in Minnesota, USA. Water 2016, 8, 549. [CrossRef]

40. Coyle, C.; Creamer, R.E.; Schulte, R.P.O.; O'Sullivan, L.; Jordan, P. A Functional Land Management conceptual framework under soil drainage and land use scenarios. Environ. Sci. Policy 2016, 56, 39-48. [CrossRef]

41. USDA-NRSC. Soil Taxonomy, 2nd ed.; Govermnent Printing Office: Washington, DC, USA, 1999. 
42. Doležal, F.; Kvítek, T. The role of recharge zones, discharge zones, springs and tile drainage systems in peneplains of Central European highlands with regard to water quality generation processes. Phys. Chem. Earth 2004, 29, 775-785. [CrossRef]

43. Herrmann, A.; Duncker, D. Runoff Formation in a Tile-drained Agricultural Basin of the Harz Mountain Foreland, Northern Germany. Soil Water Res. 2008, 3, 83-97.

44. Bauwe, A.; Tiemeyer, B.; Kahle, P.; Lennartz, B. Classifying hydrological events to quantify their impact on nitrate leaching across three spatial scales. J. Hydrol. 2015, 531, 589-601. [CrossRef]

45. Büttner, O.; Tittel, J. Uncertainties in dissolved organic carbon load estimation in a small stream. J. Hydrol. Hydromech. 2013, 61, 81-83. [CrossRef]

46. Deelstra, J.; Iital, A.; Povilaitis, A.; Kyllmar, K.; Greipsland, I.; Blicher-Mathiesen, G.; Jansons, V.; Koskiaho, J.; Lagzdins, A. Reprint of 'Hydrological pathways and nitrogen runoff in agricultural dominated catchments in Nordic and Baltic countries'. Agric. Ecosyst. Environ. 2014, 198, 211-219. [CrossRef]

47. Fučík, P.; Kaplická, M.; Kvítek, T.; Peterková, J. Dynamics of Stream Water Quality during Snowmelt and Rainfall-Runoff Events in a Small Agricultural Catchment. CLEAN 2012, 40, 154-163. [CrossRef]

48. Konečná, J.; Karásek, P.; Fučík, P.; Podhrázská, J.; Pochop, M.; Ryšavý, S.; Hanák, R. Integration of soil and water conservation measures in an intensively cultivated watershed - a case study of Jihlava River Basin (Czech Republic). Eur. Countryside 2017, 1, 17-28. [CrossRef]

49. Nováková, E.; Karous, M.; Zajíček, A.; Karousová, M. Evaluation of ground penetrating radar and vertical electrical sounding methods to determine soil horizons and bedrock at the locality Dehtáře. Soil Water Res. 2013, 8, 105-112.

50. Kennedy, C.D.; Bataille, C.; Liu, Z.; Ale, S.; VanDeVelde, J.; Roswell, C.R.; Bowling, L.C.; Bowen, G.J. Dynamics of nitrate and chloride during storm events in agricultural catchments with different subsurface drainage intensity (Indiana, USA). J. Hydrol. 2012, 466, 1-10. [CrossRef]

51. Klaus, J.; Zehe, E.; Elsner, M.; Külls, C.; McDonnell, J.J. Macropore flow of old water revisited: Experimental insights from a tile-drained hillslope. Hydrol. Earth Syst. Sci. 2013, 17, 103-118. [CrossRef]

52. Tachecí, P.; Žlábek, P.; Kvítek, T.; Peterková, J. Analysis of rainfall-runoff events in four subcatchments of the Kopaninský potok (Czech Republic). Bodenkultur 2013, 64, 105-111.

53. Merz, R.; Bloschl, G.; Parajka, J. Spatio-temporal variability of event runoff coefficients. J. Hydrol. 2006, 331, 591-604. [CrossRef] 